\title{
Vitamin D receptor as a marker of prognosis in oesophageal adenocarcinoma: a prospective cohort study
}

\author{
Stephen McCain ${ }^{1}$, James Trainor ${ }^{2}$, Damian T. McManus², Úna C. McMenamin ${ }^{1}$, \\ Stephen McQuaid ${ }^{3}$, Victoria Bingham ${ }^{3}$, Jacqueline A. James ${ }^{3}$, Manuel Salto-Tellez ${ }^{3}$, \\ Richard C. Turkington ${ }^{3}$ and Helen G. Coleman ${ }^{1,3}$ \\ ${ }^{1}$ Cancer Epidemiology Research Group, Centre for Public Health, Queen's University Belfast, Belfast, Northern Ireland \\ ${ }^{2}$ Department of Pathology, Belfast Health and Social Care Trust, Belfast, Northern Ireland \\ ${ }^{3}$ Centre for Cancer Research and Cell Biology, Queen's University Belfast, Belfast, Northern Ireland \\ Correspondence to: Stephen McCain, email: smccain02@qub.ac.uk \\ Keywords: vitamin D receptor; oesophageal cancer; oesophageal adenocarcinoma \\ Abbreviations: VDR: Vitamin D receptor \\ Received: August 22, $2018 \quad$ Accepted: September 05, $2018 \quad$ Published: September 28, 2018 \\ Copyright: McCain et al. This is an open-access article distributed under the terms of the Creative Commons Attribution License \\ 3.0 (CC BY 3.0), which permits unrestricted use, distribution, and reproduction in any medium, provided the original author and \\ source are credited.
}

\section{ABSTRACT}

Aims: Vitamin D receptor (VDR) expression has been associated with survival in several cancer sites. This study aims to evaluate the association between VDR expression and prognosis in oesophageal adenocarcinoma patients.

Results: During a median of 2.5 (maximum 9) years of follow-up, 75 patients died. In analysis adjusted for confounders, higher VDR expression was associated with an improved overall survival (HR 0.49 95\% CI 0.25-0.96) and disease-specific survival (HR $0.5095 \%$ CI 0.26-0.99), when comparing the highest with the lowest tertile of expression. These associations were strongest in sensitivity analysis restricted to junctional tumours.

Conclusions: This study is the first to demonstrate that patients with higher VDR expression in oesophageal adenocarcinoma have a more favourable prognosis. Further work is needed to validate these findings, and to define the role of VDR in the aetiology, progression and management of oesophageal adenocarcinoma.

Methods: Oesophageal adenocarcinoma specimens and clinical data were collected from 130 patients treated with neo-adjuvant chemotherapy prior to surgical resection at the Northern Ireland Cancer Centre between 2004 and 2012 . Tissue microarrays were created and immunohistochemical staining for VDR was performed on triplicate tumour cores from each resection specimen. Cox proportional hazards models were applied to evaluate associations between VDR, according to tertiles of expression, and survival outcomes.

\section{INTRODUCTION}

Oesophageal cancer causes 400,000 deaths worldwide each year and ranks as the sixth most common cause of cancer mortality [1]. Neo-adjuvant therapy has somewhat improved prognosis, however 5-year survival rates for this malignancy still only range between $10 \%$ and $18 \%$ in Western settings $[2,3]$. These low figures are partially related to more than $30 \%$ of oesophageal cancer patients having metastatic disease at first presentation [2]. Even in those patients with localised disease who have undergone attempted curative surgery, the 5-year survival is still as low as $41 \%$ [2]. In addition to early detection initiatives, there is a need to identify actionable, prognostic biomarkers to help predict patient outcome and also to identify novel therapeutic targets.

The vitamin D receptor (VDR) exerts its biological influence by binding with circulating vitamin $\mathrm{D}$, and 
thereby contributes to the regulation of apoptosis and cell differentiation, and suppression of cancer cell proliferation [4-6]. In-vitro studies within colorectal cancer cell lines have demonstrated that cells with high VDR expression tend to be well differentiated and are biologically favourable, whereas cell lines with low VDR expression demonstrated aggressive features with higher metastatic potential [7]. These findings have been translated in clinical studies which have shown that high VDR expression has been associated with increased survival in colorectal, pancreatic and breast cancer, cutaneous melanoma, urothelial bladder cancer and oesophageal squamous cell carcinoma [8-13].

To date, there has been little research investigating VDR expression and oesophageal adenocarcinoma outcomes. However, several published papers have reported differences in VDR expression when comparing native, pre-malignant and oesophageal adenocarcinoma tissue in cross-sectional analyses from different patients $[14,15]$. One study reported no VDR staining in normal oesophageal squamous mucosa, whereas Barrett's mucosa and low grade dysplasia had strongly positive VDR staining (95\% and $100 \%$, respectively), which then decreased slightly in tissue from patients with adenocarcinoma (79\%) [14]. This study is discussed in depth in the discussion section. Similar findings were observed in a small study which assessed VDR expression in tumour, adjacent normal and Barrett's mucosa, from five oesophageal adenocarcinoma resection specimens [15]. Collectively, these findings suggest that VDR expression only features in oesophageal cells after they have undergone metaplastic transition, but it is unclear if this is a cause-or-effect role. The implications of VDR expression on further progression of columnar epithelium to oesophageal adenocarcinoma, and prognosis after adenocarcinoma development remains unclear.

To date, only one study has investigated the association between VDR expression and oesophageal adenocarcinoma outcomes in 116 patients. In this patient cohort from the University of Rochester, New York, no significant difference in outcome in those patients with high compared to low VDR expression was seen [14].

This study aims to expand on this limited evidence, to investigate the association between VDR expression and prognosis in oesophageal adenocarcinoma patients who have undergone neoadjuvant chemotherapy and surgical resection.

\section{RESULTS}

\section{Patient demographics and tumour characteristics}

Of the total 130 oesophageal adenocarcinoma patients in this study, $78 \%$ were male and $22 \%$ were female. The majority of tumours were located at the gastro- oesophageal junction (84.6\%), with Siewert 1 tumours the most common $(50.8 \%)$, followed by Siewert $2(25.4 \%)$ and Siewert $3(8.5 \%)$.

Table 1 presents the patient demographics and tumour characteristics across tertiles of maximum VDR expression. There was no difference by patient sex, age at diagnosis, year of diagnosis, smoking, or alcohol status according to tertiles of VDR expression. There were fewer Siewert 1 tumours in the highest compared with the lowest tertile of VDR expression $(p=0.04)$. There was also a difference in T-stage ( $p=0.04)$ according to tertiles of VDR expression, although this mostly reflect small numbers in some categories. There was no difference in lymphovascular invasion, circumferential resection margin status, tumour differentiation or surgical nodal status according to tertiles of VDR expression.

\section{Survival analysis}

There were 75 patients who had died during a maximum of 9 (median 2.5) years of follow-up. As shown in Table 2, in unadjusted analysis, a higher VDR expression showed a trend towards significance with an improved survival. In adjusted analysis, a dose-response association between higher VDR expression and improved overall survival became apparent. In patients with tumour VDR expression in the middle tertile, there was a $40 \%$ non-significant reduced risk of death (HR 0.60 95\% CI $0.33-1.09 ; p=0.09$ ) and those in the highest tertile had a $51 \%$ significantly lower risk of death (HR $0.4995 \% \mathrm{CI}$ $0.25-0.96 ; p=0.04)$, compared with the lowest VDR expression category. This association was not as apparent in analysis evaluating high and low VDR expression as determined by the median cut-off; higher VDR expression was associated with an $18 \%$ non-significant reduced risk of death (HR 0.82 95\% CI 0.48-1.38; $p=0.45$ ) for high VDR expression compared with the low VDR expression group. Very similar patterns of results were observed in cancer-specific survival analysis (Table 2).

\section{Sensitivity analysis}

Table 3 outlines sensitivity analysis restricted to junctional tumours. As with the main analysis, higher VDR expression was associated with improved overall survival and cancer-specific survival, and the magnitude of associations were strengthened. Patients with VDR expression in the highest tertile had a significant 56\% reduction in all-cause mortality (HR 0.44 95\% CI 0.22-0.99), with similar reductions in cancer-specific mortality, although statistical significance was slightly attenuated (HR 0.47 95\% CI 0.21-1.02) compared to patients with the lowest VDR expression tumour cores.

Secondary analysis in which all above outcomes were evaluated for median, rather than maximum, VDR expression largely showed similar results that were attenuated in statistical significance (data not shown). 
Table 1: Patient demographics and tumour characteristics according to tertiles of maximum VDR expression

\begin{tabular}{|c|c|c|c|c|c|}
\hline & $\begin{array}{l}\text { Total number } \\
\qquad n=130\end{array}$ & $\begin{array}{c}\text { Tertile } 1 \\
\text { H score }<120 \\
n=48\end{array}$ & $\begin{array}{c}\text { Tertile 2 } \\
\text { H score } 120-240 \\
n=47\end{array}$ & $\begin{array}{c}\text { Tertile } 3 \\
\text { H score }>\mathbf{2 4 0} \\
n=\mathbf{3 5}\end{array}$ & $P$-value \\
\hline \multicolumn{6}{|l|}{$\overline{\text { Sex }}$} \\
\hline Male & $101(77.7)$ & $34(70.8)$ & $38(80.9)$ & $29(82.9)$ & \\
\hline Female & $29(22.3)$ & $14(29.2)$ & $9(19.2)$ & $6(17.1)$ & 0.35 \\
\hline \multicolumn{6}{|l|}{ Age at diagnosis (years) } \\
\hline$<50$ & $14(10.8)$ & $6(12.5)$ & $4(8.5)$ & $4(11.4)$ & \\
\hline $50-59$ & $25(19.2)$ & $7(14.6)$ & $11(23.4)$ & $7(20.0)$ & 0.79 \\
\hline $60-79$ & $61(46.9)$ & $26(54.2)$ & $21(44.7)$ & $14(40.0)$ & \\
\hline$\geq 80$ & $30(23.1)$ & $9(18.8)$ & $11(23.4)$ & $10(28.6)$ & \\
\hline \multicolumn{6}{|l|}{ Smoking status } \\
\hline Never smoker & $34(26.2)$ & $12(25)$ & $11(23.4)$ & $11(31.4)$ & \\
\hline Former smoker & $48(36.9)$ & $18(37.5)$ & $17(36.7)$ & $13(37.4)$ & \\
\hline Current smoker & $31(23.9)$ & $11(22.9)$ & $14(29.8)$ & $6(17.1)$ & 0.90 \\
\hline Unknown & $17(13.1)$ & $7(14.6)$ & $5(10.64)$ & $5(14.3)$ & \\
\hline \multicolumn{6}{|l|}{ Alcohol } \\
\hline Never drinker & $41(31.5)$ & $12(25.0)$ & $15(31.9)$ & $14(40.0)$ & \\
\hline Ever & $69(53.1)$ & $27(56.3)$ & $26(55.3)$ & $16(45.7)$ & 0.64 \\
\hline Unknown & $20(15.4)$ & $9(18.8)$ & $6(12.8)$ & $5(14.3)$ & \\
\hline \multicolumn{6}{|l|}{ Primary site } \\
\hline Lower third & $20(15.4)$ & $6(12.5)$ & $6(12.8)$ & $8(22.9)$ & \\
\hline $\begin{array}{l}\text { Gastro-oesophageal } \\
\text { junction }\end{array}$ & $110(84.6)$ & $42(87.5)$ & $41(87.2)$ & $27(77.1)$ & 0.36 \\
\hline \multicolumn{6}{|l|}{ Siewert classification } \\
\hline 1 & $66(50.8)$ & $24(50)$ & $31(66)$ & $11(31.4)$ & \\
\hline 2 & $33(25.4)$ & $16(33.3)$ & $6(12.8)$ & $11(31.4)$ & 0.04 \\
\hline 3 & $11(8.5)$ & $2(4.2)$ & $4(8.5)$ & $5(14.3)$ & \\
\hline \multicolumn{6}{|l|}{ PET responder } \\
\hline No & $43(33.1)$ & $16(33.3)$ & $14(29.8)$ & $13(37.1)$ & \\
\hline Yes & $57(43.9)$ & $20(41.7)$ & $22(46.8)$ & $15(42.9)$ & 0.95 \\
\hline Unknown & $32(23.1)$ & $12(25.0)$ & $11(23.4)$ & $7(20.0)$ & \\
\hline \multicolumn{6}{|l|}{$\begin{array}{l}\text { Lymphatic vascular } \\
\text { invasion }\end{array}$} \\
\hline No & $40(30.8)$ & $15(31.3)$ & $13(27.7)$ & $12(34.3)$ & \\
\hline Yes & $90(69.2)$ & $33(66.7)$ & $34(72.3)$ & $23(65.7)$ & 0.81 \\
\hline \multicolumn{6}{|l|}{$\begin{array}{l}\text { Circumferential resection } \\
\text { margin status }\end{array}$} \\
\hline Negative & $73(56.1)$ & $26(54.2)$ & $27(57.5)$ & $20(57.1)$ & \\
\hline Positive & $57(43.9)$ & $22(45.8)$ & $20(42.6)$ & $15(42.9)$ & 0.94 \\
\hline \multicolumn{6}{|l|}{ Differentiation } \\
\hline Well or Moderate & $52(40.0)$ & $22(45.8)$ & $17(36.2)$ & $13(37.1)$ & \\
\hline Moderate-Poor or Poor & $78(60.0)$ & $26(54.2)$ & $30(63.8)$ & $22(62.9)$ & 0.58 \\
\hline \multicolumn{6}{|l|}{ Surgical T stage } \\
\hline 1 & $11(8.5)$ & $6(12.5)$ & $1(2.1)$ & $4(11.4)$ & \\
\hline
\end{tabular}




\begin{tabular}{|c|c|c|c|c|c|}
\hline 2 & $25(19.2)$ & $4(8.3)$ & 15 (31.9) & $6(17.1)$ & \\
\hline 3 & $89(68.5)$ & $36(75)$ & $28(59.6)$ & $25(71.4)$ & 0.04 \\
\hline 4 & $5(3.9)$ & $2(4.2)$ & $3(6.4)$ & $0(0)$ & \\
\hline \multicolumn{6}{|c|}{ Surgical N stage } \\
\hline 0 & $44(33.9)$ & $16(33.3)$ & $16(34.0)$ & $12(34.3)$ & \\
\hline 1 & $27(20.8)$ & $11(22.9)$ & $10(21.3)$ & $6(17.1)$ & \\
\hline 2 & $29(22.3)$ & $9(18.8)$ & $13(27.7)$ & $7(20.0)$ & 0.86 \\
\hline 3 & $30(23.1)$ & $12(25.0)$ & $8(17.0)$ & $11(28.6)$ & \\
\hline
\end{tabular}

Abbreviations: PET $=$ Positive emission tomography scan; T-stage $=$ Tumour stage $; \mathrm{N}$ stage $=$ Nodal stage .

Table 2: Oesophageal adenocarcinoma survival outcomes according to Vitamin D receptor expression

\begin{tabular}{|c|c|c|c|c|c|c|}
\hline & $\begin{array}{c}\text { Dead } \\
n=75\end{array}$ & $\begin{array}{c}\text { Alive } \\
n=55\end{array}$ & $\begin{array}{c}\text { Unadjusted } \\
\text { Hazard ratio } \\
\text { (95\% CI) }\end{array}$ & $P$-value & $\begin{array}{c}\text { Adjusted } \\
\text { Hazard ratio }^{\mathrm{a}} \\
(95 \% \text { CI })\end{array}$ & $P$-value \\
\hline \multicolumn{7}{|l|}{ Overall survival } \\
\hline Low $(<$ median $)$ & 39 & 23 & 1.00 & & 1.00 & \\
\hline $\operatorname{High}(\geq$ median $)$ & 36 & 32 & $0.71(0.45-1.13)$ & 0.15 & $0.82(0.48-1.38)$ & 0.45 \\
\hline Tertile $1(<120)$ & 24 & 18 & 1.00 & & 1.00 & \\
\hline Tertile $2(120-240)$ & 31 & 17 & $0.84(0.5-1.41)$ & 0.51 & $0.60(0.33-1.09)$ & 0.09 \\
\hline Tertile $3(>240)$ & 20 & 20 & $0.65(0.36-1.20)$ & 0.17 & $0.49(0.25-0.96)$ & 0.04 \\
\hline \multicolumn{7}{|l|}{ Cancer-specific survival ${ }^{b}$} \\
\hline Low $(<$ median $)$ & 37 & 23 & 1.00 & & 1.00 & \\
\hline $\operatorname{High}(\geq$ median $)$ & 33 & 32 & $0.72(0.45-1.15)$ & 0.17 & $0.83(0.48-1.42)$ & 0.49 \\
\hline Tertile $1(<120)$ & 28 & 19 & 1.00 & & 1.00 & \\
\hline Tertile $2(120-240)$ & 26 & 18 & $0.80(0.47-1.37)$ & 0.42 & $0.55(0.29-1.04)$ & 0.06 \\
\hline Tertile $3(>240)$ & 16 & 18 & $0.69(0.37-1.27)$ & 0.23 & $0.50(0.26-0.99)$ & 0.05 \\
\hline
\end{tabular}

Abbreviations: $\mathrm{CI}=$ Confidence Intervals.

${ }^{a}$ Variables included in the adjusted analysis were age at diagnosis, gender, tumour nodal status, circumferential resection margin, tumour differentiation, lymphovascular invasion, smoking status and tumour location.

${ }^{b}$ This analysis included 125 patients as 5 had died due to other causes.

\section{DISCUSSION}

This study is the first to demonstrate a significant, dose-response, association between higher VDR expression and improved survival in patients with oesophageal adenocarcinoma. Sensitivity analysis also demonstrated that the association between higher VDR expression and improved survival was particularly evident in patients with oesophago-gastric junctional tumours.

These findings contrast with those from the only other published study to have considered the impact of VDR expression on oesophageal cancer survival. In a study of 116 patients in the USA, no significant difference in overall survival (21 months in high VDR expression versus 20 months in low VDR expression) was demonstrated between groups with high and low VDR expression $(p=0.99)$ [14]. There are multiple differences in that study's design compared with ours that may account for the conflicting results. Firstly, in our study, all patients underwent neoadjuvant treatment prior to surgical resection, whilst in the aforementioned study all patients had surgical resection without neo-adjuvant therapy [14]. Limited research is available to explore the impact of neoadjuvant treatment upon VDR expression of the primary tumour, although one small study in 15 patients found those with higher VDR expression were less likely to respond to treatment, indicating a potential interaction [16]. However, the authors accepted that these results could be simply due to chance [16]. Secondly, the methods of scoring and analysing the VDR expression differed in that there was only one sample taken for each patient and there was considered to be a high expression of VDR if $10 \%$ or more of cells stained with an intensity score of $2+$ or 3+ [14]. This would be the equivalent of an $\mathrm{H}$-score of 20 or 30 in our study to divide patients into high and low expression, whereas our lowest tertile reflected an H-score of less than 120. Our methods also involved scoring three cores rather than one from each tumour specimen, which 
Table 3: Sensitivity analysis of oesophageal adenocarcinoma survival outcomes according to Vitamin D receptor expression, restricted to junctional tumours only

\begin{tabular}{|c|c|c|c|c|}
\hline & $\begin{array}{c}\text { Dead } \\
n=67\end{array}$ & $\begin{array}{c}\text { Alive } \\
n=43\end{array}$ & $\begin{array}{c}\text { Adjusted } \\
\text { Hazard ratio }^{\mathrm{a}} \\
(95 \% \mathrm{CI})\end{array}$ & $P$-value \\
\hline \multicolumn{5}{|l|}{ Overall survival } \\
\hline Tertile $1(<120)$ & 25 & 17 & 1.00 & \\
\hline Tertile $2(120-240)$ & 26 & 15 & $0.50(0.26-0.97)$ & 0.04 \\
\hline Tertile $3(>240)$ & 16 & 11 & $0.46(0.21-0.98)$ & 0.04 \\
\hline \multicolumn{5}{|l|}{ Cancer-specific survival ${ }^{b}$} \\
\hline Tertile $1(<120)$ & 24 & 17 & 1.00 & \\
\hline Tertile $2(120-240)$ & 23 & 15 & $0.44(0.21-0.89)$ & 0.02 \\
\hline Tertile $3(>240)$ & 15 & 11 & $0.47(0.22-1.02)$ & 0.05 \\
\hline
\end{tabular}

Abbreviations: $\mathrm{CI}=$ Confidence Intervals.

a Variables included in the adjusted analysis were age at diagnosis, gender, tumour nodal status, circumferential resection margin, tumour differentiation, lymphovascular invasion, and smoking status.

${ }^{b}$ This analysis included 105 patients as opposed to 110 patients as in the overall survival analysis as 5 had died due to other causes.

reduces the likelihood of sampling bias. Thirdly, there may be underlying differences in the population studied (Northern Ireland and the USA) and fourthly, this study used a different antibody to stain the specimens. All of these factors may account somewhat for the difference in findings.

Although there is limited research looking at the impact of high VDR expression in oesophageal adenocarcinoma outcomes, there are multiple other clinical studies which look at the impact of high VDR expression on survival in patients with other cancer sites. Some, but not all, studies within colorectal cancer patients have demonstrated that higher VDR expression is associated with improved survival $[8,17,18]$. A single study looking at the impact of VDR expression on survival in pancreatic adenocarcinoma performed in a Chinese population of 61 patients found that patients with high VDR expression survived longer than those with low or no VDR expression [9]. Similar results were found in a single study looking at the impact of VDR expression in cholangiocarcinoma in a Thai study of 111 patients. Patients with no VDR expression had a 2-fold higher increased risk of death than in patients whose tumours expressed VDR (HR 2.00 95\% CI 1.07-3.76) [19]. Studies in melanoma skin cancer, breast cancer, oesophageal squamous cell carcinoma and urothelial bladder cancer have also found similar findings with improved overall survival and progression free survival in patients with higher VDR expression within the tumour tissue [11-12].

Another interesting feature of previous studies in other cancer sites was that higher VDR expression was more frequently observed in well differentiated tumours compared to poorly differentiated tumours in colorectal cancer, pancreatic adenocarcinoma and cholangiocarcinoma $[8,9,19]$. This corroborates similar findings in a previous study by Trowbridge et al. in tissue from 15 oesophageal adenocarcinoma patients [16]. In our study however, there was no association between tumour grade and VDR expression, and adjustment for grade within our survival analysis did not affect our results.

When we performed sensitivity analysis for junctional tumours only, there was a greater magnitude of association between VDR expression and overall survival and disease-specific survival, although statistical significance was slightly attenuated for the latter. Previous findings suggest that VDR expression only features in oesophageal cells after they have undergone metaplastic transition, but it is unclear if this is a cause-or-effect role $[15,20]$. Our findings in the sensitivity analysis may therefore arise due to a difference in VDR expression between tumour sites. This theory is supported by the fact that junctional tumours can arise from oesophageal tissue or gastric tissue and these tissues may differ biologically in both their normal state and pre-malignant state.

Evidence from our study demonstrates for the first time that any association between circulating vitamin $\mathrm{D}$ levels and oesophageal adenocarcinoma outcomes, mediated by VDR expression, may be biologically plausible. VDR are activated when they combine with vitamin $\mathrm{D}_{3}$, the active form of vitamin $\mathrm{D}$. This subsequently combines with the retinoid $\mathrm{x}$ receptor which can then promote or suppress hallmarks of tumorigenesis [5, 6]. Indeed, a cell-line study has demonstrated that VDR activation regulates apoptosis and cell differentiation, and suppresses tumour proliferation [4]. However, further studies that incorporate assessment of serum 25-hydroxyvitamin $\mathrm{D}$ status in addition to tumour VDR expression in patients with oesophageal adenocarcinoma are required to corroborate this hypothesis. 
Research into the impact of vitamin D with respect to oesophageal adenocarcinoma risk is highly controversial, with observational studies having reported null results, decreased risks, or indeed increased risks of oesophageal adenocarcinoma in patients with higher levels of vitamin D intake or status [21-24]. No clear associations for circulating vitamin $\mathrm{D}$ levels and prognosis after a diagnosis of oesophageal cancer were identified in a European cohort study, although that included only 74 adenocarcinoma patients [25]. Our study provides some evidence that VDR is associated with oesophageal adenocarcinoma outcomes, and therefore indirect evidence of a biological role for vitamin D.

One observational study has investigated the impact of post-operative vitamin D supplementation in patients having undergone surgical resection for their oesophageal squamous cell carcinoma [26]. There were 280 patients with oesophageal squamous cell carcinoma and of these there were 49 patients who took daily vitamin D supplements of between 200-400 international units daily [26]. Although vitamin D supplement use was not associated with improved overall survival, it was associated with a $39 \%$ reduction in disease recurrence in adjusted analysis (HR $0.6195 \%$ CI 0.38-0.98) [26]. This demonstrates the role that vitamin D may play in the postoperative phase in oesophageal squamous cell carcinoma.

Theoretically, if VDR levels impact on survival and vitamin D activates the VDR, then vitamin D may play a role in the neo-adjuvant treatment phase or even in the chemo-preventative setting $[3,27]$. This hypothesis is supported by findings in other cancers with in-vivo studies in colorectal, pancreatic and gastric cancer having shown 1,25-dihydroxyvitamin $\mathrm{D}_{3}$ 25-hydroxyvitamin $\mathrm{D}_{3}$ and vitamin $\mathrm{D}$ analogues to decrease cancer cell growth [28-30]. Furthermore, results in animal models have been encouraging as vitamin D3 has been shown to decrease both pre-cancerous and cancerous lesions in gastric cancer in rats [31].

This study has several strengths, including being the first study to identify VDR as potential biomarker to predict outcomes in oesophageal adenocarcinoma, and only the second study to investigate this association. Furthermore, our study was performed in a population which has low exposure to vitamin $\mathrm{D}$ and a high incidence of oesophageal adenocarcinoma [2, 32]. Survival remains poor in this disease with limited treatment options and this study enables hypothesis generation around the role of vitamin $\mathrm{D}$ analogues in the management of oesophageal adenocarcinoma [33].

The main limitation of this study is the relatively small sample size, although our cohort size of 130 patients is typical of this relatively rare disease site. All patients had surgically resectable disease, therefore this cohort represents patients with more favourable prognosis, and we cannot deduce if VDR expression impacts upon the outcome in patients with more advanced disease. Future studies should aim to evaluate associations between VDR expression and survival in patients with advanced disease as has been demonstrated for other cancer sites, however given the limited expected survival within this group of patients it may be difficult to detect significant benefits [34].

In conclusion, in this Northern Irish population, patients with higher VDR expression in oesophageal adenocarcinoma have a more favourable prognosis. However, further work is needed to validate these findings and define the role of VDR in the aetiology, management and progression of oesophageal adenocarcinoma.

\section{MATERIALS AND METHODS}

This study was performed and reported in line with the REMARK guidelines [35].

\section{Patient selection}

In this population-representative study, all patients in Northern Ireland who underwent neoadjuvant chemotherapy followed by surgical resection for oesophageal adenocarcinoma between the 1st January 2004 and the 31st December 2012 were included. There were 158 formalin-fixed paraffin embedded (FFPE) oesophageal adenocarcinoma resection specimens collected from the Northern Ireland Cancer Centre. Of these, slides with tumour which could be scored and matched clinical information was available for 137 patients. Seven patients were excluded from further analysis, as two were staged as T0 disease, one had metastatic disease, and tissue microarray (TMA) cores were unable to be scored for VDR expression for four patients, leaving 130 patients for inclusion in our final analysis. Figure 1 summarises the indications for exclusion from this study.

\section{Clinical data}

Clinical data and information on study outcomes up until 31st December 2014 was retrieved via patient note review at the Northern Ireland Cancer Centre. Information included age at diagnosis, date of diagnosis, date of surgery, patient sex, smoking and alcohol status. Pathology reports were reviewed for tumour characteristics including tumour location, presence of lymphovascular invasion, circumferential resection margin status, tumour differentiation and TNM stage. Tumour location was divided into lower third of oesophagus (greater than $5 \mathrm{~cm}$ proximal to the oesophagogastric junction), Siewert 1 (within 1-5 cm above the oesophagogastric junction), Siewert 2 (within $1 \mathrm{~cm}$ above and $2 \mathrm{~cm}$ below the oesophagogastric junction) and Siewert $3 \quad(2-5 \mathrm{~cm}$ below the oesophagogastric junction) [36]. Pathological staging was 
defined according to International Union Against Cancer (UICC) TNM staging, 7th edition [37]. Finally, the date and cause of death were recorded, where applicable.

\section{Construction of tissue microarrays}

A FFPE tissue block was selected from each resection specimen and three $1 \mathrm{~mm}$ cores of tumour were embedded in a paraffin block using the Beecher Manual Arrayer ${ }^{\circledR}$.

\section{Immunohistochemistry staining and scoring}

Immunohistochemical analysis was performed within the NI-Molecular Pathology Laboratory (NI-MPL) at Queen's University Belfast, following approval by the Northern Ireland Biobank (study number NIB15-0176). Slides were immunostained on a Ventana BenchMark fully automated immunostainer, with a previously validated rabbit monoclonal VDR antibody (cell signalling-clone number D2K6W: 1/100, pre-treatment CC1 32 minutes, Optiview detection without amplification) to enable VDR expression to be identified and then scanned on an Aperio AT2 scanner, and viewed as digital images on Xplore (PathXL).

Biomarker expression was evaluated by a trainee pathologist (JT) and an independent observer (surgical registrar, $\mathrm{SMcC}$ ), who were both blinded to clinical data. This process was carried out following the training and guidance of an expert gastrointestinal pathologist $(\mathrm{DMcM})$. The staining intensity from each tissue section was assessed along with the percentage of tumour cells staining positive and a final agreement on discordant results was made. Scoring was based on intensity $(0=$ no staining, $1=$ weak, $2=$ moderate and $3=$ strong staining observed) and this was multiplied with the percentage of tumour cells staining positive to give an H-score between 0 and 300. Examples of these different grades of staining are demonstrated in Figure 2. Different methods for evaluating the VDR expression are reported in the literature and may contribute to different results. A range of these methods are displayed in Table 4.

\section{Statistical analysis}

Median and maximum H-scores for VDR expression across the triplicate tumour cores were generated for each patient, to explore if there was an association with outcomes. Following evaluation of histograms, the median and maximum H-scores were used to create groupings of both high/low VDR expression and tertiles of high/ medium/low VDR expression, although the distributions in the histograms did appear to favour the latter method. Primary analysis evaluated the distribution based on the maximum $\mathrm{H}$-score (which may be more clinically relevant) from the triplicate cores in TMAs, and median H-scores (which may be less subject to sampling errors) were evaluated in secondary analysis.

Patient demographics and tumour characteristics according to tumour VDR status were compared using chisquared tests. Outcomes studied included the impact of VDR expression across tertiles on overall survival (death from any cause) and cancer-specific survival (death from

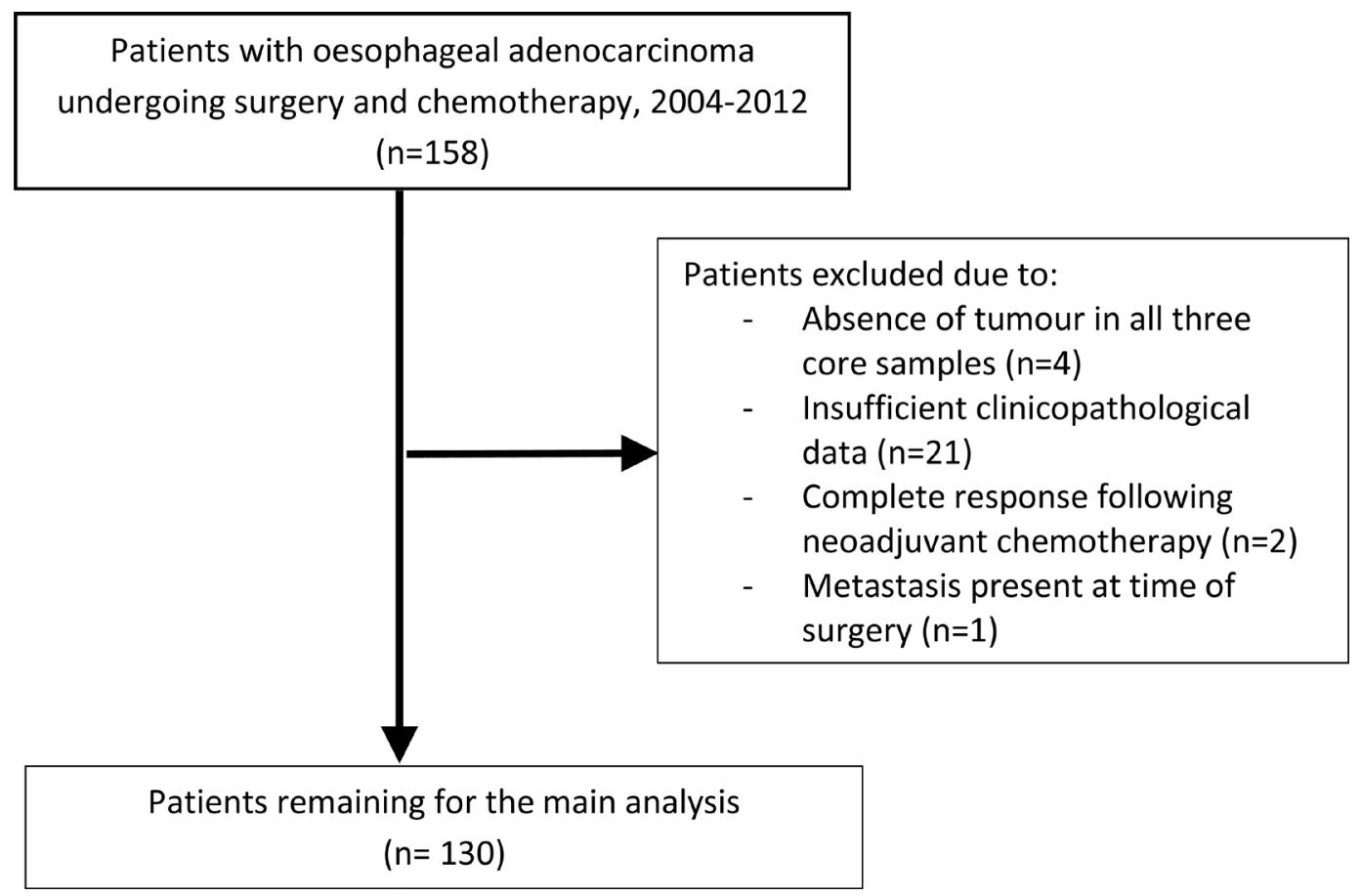

Figure 1: Flow chart demonstrating reasons for patient exclusion from study. 
Table 4: Different methods of calculating the VDR expression in other studies

\begin{tabular}{|c|c|c|c|c|c|}
\hline Study author & Type of cancer & $\begin{array}{l}\text { Method of staining for } \\
\text { VDR }\end{array}$ & $\begin{array}{l}\text { Method of scoring } \\
\text { grade of staining }\end{array}$ & $\begin{array}{l}\text { Method of scoring } \\
\text { percentage of cells } \\
\text { staining positive }\end{array}$ & $\begin{array}{l}\text { Description of how the } \\
\text { overall score and cut off } \\
\text { points were calculated }\end{array}$ \\
\hline Our study & $\begin{array}{l}\text { Oesophageal } \\
\text { adenocarcinoma }\end{array}$ & $\begin{array}{l}\text { Rabbit monoclonal VDR } \\
\text { antibody }\end{array}$ & $\begin{array}{l}\text { 0-no staining } \\
\text { 1-Weak } \\
\text { 2-Moderate } \\
\text { 3-Strong }\end{array}$ & $\begin{array}{l}\text { Percentage of tumour } \\
\text { cells staining positive }\end{array}$ & $\begin{array}{l}\text { Grade multiplied by } \\
\text { percentage to give H-score } \\
\text { between } 0-300\end{array}$ \\
\hline Zhou et al. [14] & $\begin{array}{l}\text { Oesophageal } \\
\text { adenocarcinoma }\end{array}$ & $\begin{array}{l}\text { Mouse mono-clonal } \\
\text { anti-VDR antibody }\end{array}$ & $\begin{array}{l}\text { 0-no staining } \\
1+\text { Weak } \\
\text { 2+Moderate } \\
3+\text { Strong }\end{array}$ & $\begin{array}{l}>\text { or }<\text { than } 10 \% \text { of tumour } \\
\text { cells staining positive }\end{array}$ & $\begin{array}{l}\text { If } 10 \% \text { or more of cells } \\
\text { stained } 2+\text { or } 3+\text { was deemed } \\
\text { to have high expression }\end{array}$ \\
\hline Wang et al. [9] & $\begin{array}{l}\text { Pancreatic } \\
\text { adenocarcinoma }\end{array}$ & $\begin{array}{l}3,3 \text { diaminobenzidine } \\
\text { with western blot }\end{array}$ & $\begin{array}{l}\text { 0-no staining } \\
\text { 1-Weak } \\
\text { 2-Moderate } \\
\text { 3-Strong }\end{array}$ & $\begin{array}{l}\text { Score } 0(<5 \%) \\
\text { Score } 1(6-25 \%) \\
\text { Score } 2(26-50 \%) \\
\text { Score } 3(51-75 \%) \\
\text { Score } 4(76-100 \%)\end{array}$ & $\begin{array}{l}\text { Grade score multiplied by } \\
\text { percentage score. Maximum } \\
\text { of } 12 \text { with }<4 \text { low expression } \\
\text { and } 4 \text { or greater high } \\
\text { expression }\end{array}$ \\
\hline $\begin{array}{l}\text { Seubwai et al. } \\
\text { [22] }\end{array}$ & Cholangiocarcinoma & $\begin{array}{l}\text { Rat anti-VDR } \\
\text { monoclonal antibody }\end{array}$ & Did not score grade & $\begin{array}{l}0=\text { negative } \\
1+(1 \%-25 \%) \\
2+(26 \%-50 \%) \\
3+(>50 \%)\end{array}$ & $\begin{array}{l}\text { Patients were grouped into } \\
\text { one of the four groups as per } \\
\text { the percentage of staining. } \\
\text { Analysis often involved } \\
\text { presence versus absence of } \\
\text { VDR }\end{array}$ \\
\hline $\begin{array}{l}\text { Ditsch et al. } \\
{[10]}\end{array}$ & Breast Cancer & $\begin{array}{l}\text { Vitamin D antibody } \\
\text { (monoclonal clone } 2 \mathrm{~F} 4 \\
\text { isotype IgG2a, } \mathrm{AbD} \\
\text { Serotec) }\end{array}$ & $\begin{array}{l}\text { 0-no staining } \\
\text { 1-Weak } \\
\text { 2-Moderate } \\
\text { 3-Strong }\end{array}$ & $\begin{array}{l}0=\text { negative } \\
1=<10 \% \\
2=11 \%-50 \% \\
3=51 \%-80 \% \\
4=>81 \%\end{array}$ & $\begin{array}{l}\text { Grade was multiplied by } \\
\text { percenatage that stained } \\
\text { positive with a maximum } \\
\text { score of } 12.0-1 \text { indicated no } \\
\text { staining, } 2-4 \text { was moderate } \\
\text { staining and 6-12 was high } \\
\text { staining }\end{array}$ \\
\hline $\begin{array}{l}\text { Brozna et al. } \\
{[11]}\end{array}$ & Cutaneous melanoma & $\begin{array}{l}\text { Monoclonal antibodies } \\
\text { (clone 97A, Abcam Inc, } \\
\text { Cambridge) }\end{array}$ & $\begin{array}{l}\text { 0-no staining } \\
\text { 1-Weak } \\
\text { 2-Moderate } \\
\text { 3-Strong }\end{array}$ & Did not score percentage & $\begin{array}{l}\text { Cut off points were as per } \\
\text { the three levels of grading }\end{array}$ \\
\hline
\end{tabular}

A

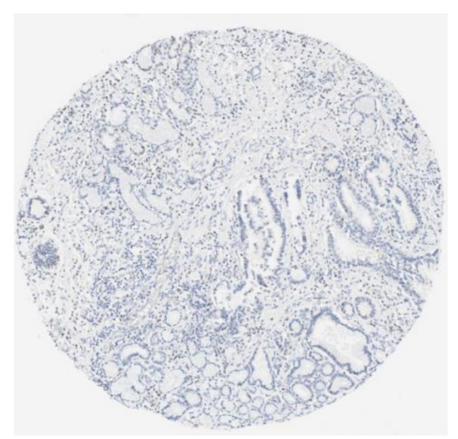

C

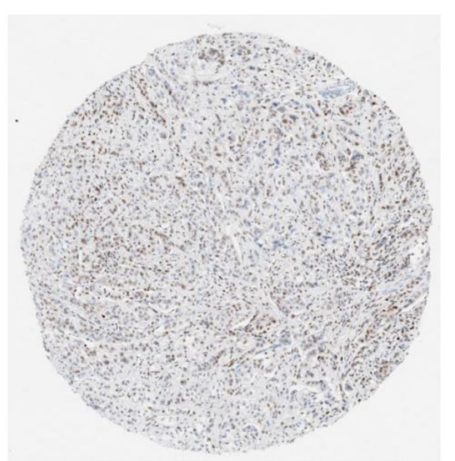

B

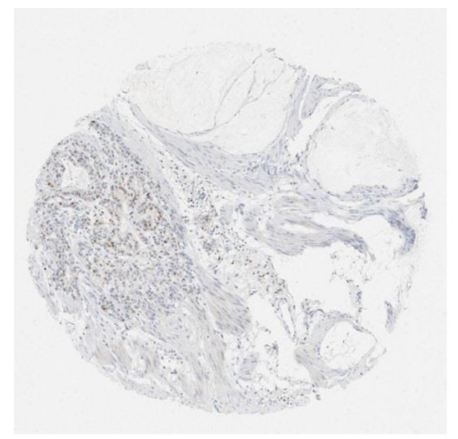

D

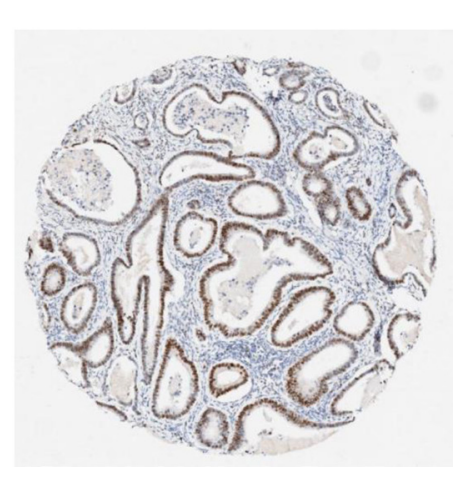

Figure 2: (A) no staining [intensity 0]; (B) weak staining [intensity 1]; (C) moderate staining [intensity 2]; (D) strong staining [intensity 3]. 
oesophageal adenocarcinoma). Comparison between VDR status and prognosis was evaluated using Cox proportional hazards regression models for unadjusted and adjusted results. The variables included in the adjusted analysis were age at diagnosis, gender, tumour nodal status, circumferential resection margin, tumour differentiation, lymphovascular invasion, smoking status and tumour location. Sensitivity analysis was performed for junctional tumours separately. Stata version 14.2 (College Station, TX, USA) was used for statistical analysis.

\section{Author contributions}

Conception and design- DMcM, SMcC, HC, RT, MST; Provision of study materials or patients- HC, RT, $\mathrm{SMcC}$; Collection and assembly of data- $\mathrm{SMcC}, \mathrm{SMcQ}$, VB, JJ, JT, RT, UMcM; Data analysis and interpretationSMcC, HC, RT; Manuscript writing- all authors; Final approval of manuscript- all authors.

\section{CONFLICTS OF INTEREST}

The authors declare no conflicts of interest

\section{Editorial note}

This paper has been accepted based in part on peerreview conducted by another journal and the authors' response and revisions as well as expedited peer-review in Oncotarget.

\section{REFERENCES}

1. IARC. Globocan 2012. 2012. Available from http:// globocan.iarc.fr/Pages/fact_sheets_cancer.aspx.

2. Oesophageal cancer survival statistics. Cancer Research UK. 2014. Available from http://www. cancerresearchuk.org/health-professional/cancer-statistics/ statistics-by-cancer-type/oesophageal-cancer/survival.

3. van Hagen P, Hulshof MC, van Lanschot JJ, Steyerberg EW, van Berge Henegouwen MI, Wijnhoven BP, Richel DJ, Nieuwenhuijzen GA, Hospers GA, Bonenkamp JJ, Cuesta MA, Blaisse RJ, Busch OR, et al, and CROSS Group. Preoperative chemoradiotherapy for esophageal or junctional cancer. N Engl J Med. 2012; 366:2074-84. https://doi.org/10.1056/NEJMoa1112088.

4. Deeb KK, Trump DL, Johnson CS. Vitamin D signalling pathways in cancer: potential for anticancer therapeutics. Nat Rev Cancer. 2007; 7:684-700. https://doi.org/10.1038/ $\operatorname{nrc} 2196$.

5. Picotto G, Liaudat AC, Bohl L, Tolosa de Talamoni N. Molecular aspects of vitamin D anticancer activity. Cancer Invest. 2012; 30:604-14. https://doi.org/10.3109/07357907 .2012 .721039 .
6. Fleet JC, DeSmet M, Johnson R, Li Y. Vitamin D and cancer: a review of molecular mechanisms. Biochem J. 2012; 441:61-76. https://doi.org/10.1042/BJ20110744.

7. Shabahang M, Buras RR, Davoodi F, Schumaker LM, Nauta RJ, Evans SR. 1,25-Dihydroxyvitamin D3 receptor as a marker of human colon carcinoma cell line differentiation and growth inhibition. Cancer Res. 1993; 53:3712-18.

8. Evans SR, Nolla J, Hanfelt J, Shabahang M, Nauta RJ, Shchepotin IB. Vitamin D receptor expression as a predictive marker of biological behavior in human colorectal cancer. Clin Cancer Res. 1998; 4:1591-95.

9. Wang K, Dong M, Sheng W, Liu Q, Yu D, Dong Q, Li Q, Wang J. Expression of vitamin D receptor as a potential prognostic factor and therapeutic target in pancreatic cancer. Histopathology. 2015; 67:386-97. https://doi.org/10.1111/ his. 12663.

10. Ditsch N, Toth B, Mayr D, Lenhard M, Gallwas J, Weissenbacher T, Dannecker C, Friese K, Jeschke U. The association between vitamin $\mathrm{D}$ receptor expression and prolonged overall survival in breast cancer. J Histochem Cytochem. 2012; 60:121-29. https://doi. org/10.1369/0022155411429155.

11. Brożyna AA, Jóźwicki W, Slominski AT. Decreased VDR expression in cutaneous melanomas as marker of tumor progression: new data and analyses. Anticancer Res. 2014; $34: 2735-43$.

12. Jóźwicki W, Brożyna AA, Siekiera J, Slominski AT. Expression of vitamin D receptor (VDR) positively correlates with survival of urothelial bladder cancer patients. Int J Mol Sci. 2015; 16:24369-86. https://doi. org/10.3390/ijms161024369.

13. Bao Y, Zhang S, Guo Y, Wei X, Zhang Y, Yang Y, Zhang H, Ma M, Yang W. Stromal expression of JNK1 and VDR is associated with the prognosis of esophageal squamous cell carcinoma. Clin Transl Oncol. 2018; 20:1185-95. https:// doi.org/10.1007/s12094-018-1843-2.

14. Zhou Z, Xia Y, Bandla S, Zakharov V, Wu S, Peters J, Godfrey TE, Sun J. Vitamin D receptor is highly expressed in precancerous lesions and esophageal adenocarcinoma with significant sex difference. Hum Pathol. 2014; 45:174451. https://doi.org/10.1016/j.humpath.2014.02.029.

15. Trowbridge R, Mittal SK, Sharma P, Hunter WJ, Agrawal DK. Vitamin D receptor expression in the mucosal tissue at the gastroesophageal junction. Exp Mol Pathol. 2012; 93:246-49. https://doi.org/10.1016/j.yexmp.2012.05.007.

16. Trowbridge R, Sharma P, Hunter WJ, Agrawal DK. Vitamin D receptor expression and neoadjuvant therapy in esophageal adenocarcinoma. Exp Mol Pathol. 2012; 93:147-53. https://doi.org/10.1016/j.yexmp.2012.04.018.

17. Ferrer-Mayorga G, Gómez-López G, Barbáchano A, Fernández-Barral A, Peña C, Pisano DG, Cantero R, Rojo F, Muñoz A, Larriba MJ. Vitamin D receptor expression and associated gene signature in tumour stromal fibroblasts predict clinical outcome in colorectal cancer. Gut. 2017; 66:1449-62. https://doi.org/10.1136/gutjnl-2015-310977. 
18. Kure S, Nosho K, Baba Y, Irahara N, Shima K, Ng K, Meyerhardt JA, Giovannucci EL, Fuchs CS, Ogino S. Vitamin D receptor expression is associated with PIK3CA and KRAS mutations in colorectal cancer. Cancer Epidemiol Biomarkers Prev. 2009; 18:2765-72. https://doi. org/10.1158/1055-9965.EPI-09-0490.

19. Seubwai W, Wongkham C, Puapairoj A, Khuntikeo N, Wongkham S. Overexpression of vitamin D receptor indicates a good prognosis for cholangiocarcinoma: implications for therapeutics. Cancer. 2007; 109:2497-505. https://doi.org/10.1002/cncr.22716.

20. De Gottardi A, Dumonceau JM, Bruttin F, Vonlaufen A, Morard I, Spahr L, Rubbia-Brandt L, Frossard JL, Dinjens WN, Rabinovitch PS, Hadengue A. Expression of the bile acid receptor FXR in Barrett's esophagus and enhancement of apoptosis by guggulsterone in vitro. Mol Cancer. 2006; 5:48. https://doi.org/10.1186/1476-4598-5-48.

21. Abnet CC, Chen Y, Chow WH, Gao YT, Helzlsouer KJ, Le Marchand L, McCullough ML, Shikany JM, Virtamo J, Weinstein SJ, Xiang YB, Yu K, Zheng W, et al. Circulating 25-hydroxyvitamin D and risk of esophageal and gastric cancer: Cohort Consortium Vitamin D Pooling Project of Rarer Cancers. Am J Epidemiol. 2010; 172:94-106. https:// doi.org/10.1093/aje/kwq121.

22. Zgaga L, O'Sullivan F, Cantwell MM, Murray LJ, Thota PN, Coleman HG. Markers of Vitamin D Exposure and Esophageal Cancer Risk: A Systematic Review and Meta-analysis. Cancer Epidemiol Biomarkers Prev. 2016; 25:877-86. https://doi.org/10.1158/1055-9965.EPI-15-1162.

23. Chen W, Dawsey SM, Qiao YL, Mark SD, Dong ZW, Taylor PR, Zhao P, Abnet CC. Prospective study of serum 25(OH)-vitamin D concentration and risk of oesophageal and gastric cancers. Br J Cancer. 2007; 97:123-28. https:// doi.org/10.1038/sj.bjc.6603834.

24. Tran B, Lucas R, Kimlin M, Whiteman D, Neale R, and Australian Cancer Study. Association between ambient ultraviolet radiation and risk of esophageal cancer. Am J Gastroenterol. 2012; 107:1803-13. https://doi.org/10.1038/ ajg.2012.329.

25. Fanidi A, Muller DC, Midttun $\varnothing$, Ueland PM, Vollset SE, Relton C, Vineis P, Weiderpass E, Skeie G, Brustad M, Palli D, Tumino R, Grioni S, et al. Circulating vitamin D in relation to cancer incidence and survival of the head and neck and oesophagus in the EPIC cohort. Sci Rep. 2016; 6:36017. https://doi.org/10.1038/srep36017.

26. Wang L, Wang C, Wang J, Huang X, Cheng Y. Longitudinal, observational study on associations between postoperative nutritional vitamin D supplementation and clinical outcomes in esophageal cancer patients undergoing esophagectomy. Sci Rep. 2016; 6:38962. https://doi.org/10.1038/srep38962.
27. Cunningham D, Allum WH, Stenning SP, Thompson JN, Van de Velde CJ, Nicolson M, Scarffe JH, Lofts FJ, Falk SJ, Iveson TJ, Smith DB, Langley RE, Verma M, et al, and MAGIC Trial Participants. Perioperative chemotherapy versus surgery alone for resectable gastroesophageal cancer. N Engl J Med. 2006; 355:11-20. https://doi.org/10.1056/ NEJMoa055531.

28. Bao A, Li Y, Tong Y, Zheng H, Wu W, Wei C. Tumorsuppressive effects of 1, 25-dihydroxyvitamin D3 in gastric cancer cells. Hepatogastroenterology. 2013; 60:943-48.

29. $\mathrm{Ng} \mathrm{K}$. Vitamin D for prevention and treatment of colorectal cancer: what is the evidence? Curr Colorectal Cancer Rep. 2014; 10:339-45. https://doi.org/10.1007/ s11888-014-0238-1.

30. Albrechtsson E, Jonsson T, Möller S, Höglund M, Ohlsson $\mathrm{B}$, Axelson J. Vitamin D receptor is expressed in pancreatic cancer cells and a vitamin D3 analogue decreases cell number. Pancreatology. 2003; 3:41-46. https://doi. org/10.1159/000069149.

31. Ikezaki S, Nishikawa A, Furukawa F, Kudo K, Nakamura H, Tamura K, Mori H. Chemopreventive effects of curcumin on glandular stomach carcinogenesis induced by N-methylN'-nitro-N-nitrosoguanidine and sodium chloride in rats. Anticancer Res. 2001; 21:3407-11.

32. Cancer Research UK. Vitamin D | Cancer Research UK. 2017. Available from http://www.cancerresearchuk.org/ about-cancer/causes-of-cancer/sun-uv-and-cancer/vitamin-d.

33. Hargrove L, Francis T, Francis H. Vitamin D and GI cancers: shedding some light on dark diseases. Ann Transl Med. 2014; 2:9. https://doi.org/10.3978/j. issn.2305-5839.2013.03.04.

34. Matusiak D, Murillo G, Carroll RE, Mehta RG, Benya RV. Expression of vitamin D receptor and 25-hydroxyvitamin D3-1 \{alpha\}-hydroxylase in normal and malignant human colon. Cancer Epidemiol Biomarkers Prev. 2005; 14:2370 76. https://doi.org/10.1158/1055-9965.EPI-05-0257.

35. Altman DG, McShane LM, Sauerbrei W, Taube SE. Reporting recommendations for tumor marker prognostic studies (REMARK): explanation and elaboration. BMC Med. 2012; 10:51. https://doi.org/10.1186/1741-7015-10-51.

36. Curtis NJ, Noble F, Bailey IS, Kelly JJ, Byrne JP, Underwood TJ. The relevance of the Siewert classification in the era of multimodal therapy for adenocarcinoma of the gastro-oesophageal junction. J Surg Oncol. 2014; 109:20207. https://doi.org/10.1002/jso.23484.

37. Rice TW, Blackstone EH. Esophageal cancer staging: past, present, and future. Thorac Surg Clin. 2013; 23:461-69. https://doi.org/10.1016/j.thorsurg.2013.07.004. 